\title{
Evaluasi Kinerja First Hop Redundancy Protocols untuk Topologi Star di Routing EIGRP
}

\author{
PRAMAWAHYUDI, RAMDHANI SYAHPUTRA, AHMAD RIDWAN
}

\author{
Postgraduated School of Electrical Engineering Universitas Andalas, Indonesia \\ Email : pramawahyudi@Iptik.unand.ac.id
}

Received 29 Maret 2020 | Revised 10 April 2020 | Accepted 12 Mei 2020

\begin{abstract}
ABSTRAK
Dalam perancangan jaringan, yang terpenting adalah faktor ketersediaan, mengurangi kegagalan, dan mengatasi beban lalu lintas yang besar. Penelitian ini bertujuan mengimplementasikan dan mengevaluasi sistem First Hop Redundancy Protocol (FHRP) pada jaringan topologi star dengan menggunakan routing EIGRP. Hasil dari pengujian kinerja rata-rata delay menunjukkan selisih antara router master dan backup pada protokol Virtual Router Redundancy Protocol (VRRP) lebih baik yaitu hanya 0,003 detik, sedangkan pada protokol Gateway Load Balancing Protocol (GLBP) 0,076 detik dan protokol Hot Standby Router Protocol (HSRP) 0,075 detik. Pada pengujian rata-rata packet loss protokol GLBP menunjukkan selisih yang cukup besar antara router master dan backup yaitu $12,07 \%$, sedangkan pada protokol VRRP 0,07 \% dan protokol HSRP 5,06\%. Namun pada hasil pengujian rata-rata throughtput protokol HSRP lebih stabil yaitu 0,60 Kbps pada router master dan 0,90 Kbps pada router backup, sedangkan protokol VRRP paling tidak stabil karena mengalami kenaikan yang signifikan yaitu 0,458 Kbps pada router master dan 1,11 Kbps pada router backup.
\end{abstract}

Kata kunci: FHRP, VRRP, GLBP, HSRP, Routing, EIGRP, Protokol

\begin{abstract}
There are several important considerations in designing a network, including availability, minimizing failure, and handling high traffic data. The current research aims to implement and evaluate the First Hop Redundancy Protocol (FHRP) system on star topology networks using EIGRP routing. The result shows the average performance difference of the master and the backup router in Virtual Router Redundancy Protocol (VRRP) protocol is 0,003 second, while in Gateway Load Balancing Protocol (GLBP) protocol is 0,076 second, and Hot Standby Router Protocol (HSRP) protocol is 0,075 second. The test in GLBP protocol shows a significant difference in packet loss between master and backup router about $12,07 \%$, while in VRRP protocol is 0,07\%, and HSRP protocol is 5,06\%. The average throughput in HSRP protocol is stable with 0,60 Kbps in the master router and 0,90 in the backup router, while in VRRP protocol is not stable with 0,458 Kbps in the master router and 1,11 Kbps in the backup router.
\end{abstract}

Keywords: FHRP, VRRP, GLBP, HSRP, Routing, EIGRP, Protocol 


\section{PENDAHULUAN}

Saat ini ketersediaan layanan jaringan internet sangat penting bagi masyarakat di Indonesia khususnya organisasi, perusahaan, dan lembaga pendidikan. Berdasarkan data survei yang dikeluarkan oleh Asosiasi Penyelenggara Jasa Internet Indonesia (APJII) tahun 2018 terjadi kenaikan jumlah pengguna internet di Indonesia sebesar $10,12 \%$ dari tahun sebelumnya (APJII, 2019). Di satu sisi, kenyamanan yang dibawa oleh sistem jaringan tidak dapat dilupakan, sehingga keandalan sistem jaringan semakin penting. Dimana permintaan utama dari pengguna jaringan area lokal (LAN) adalah berkomunikasi dengan jaringan publik eksternal tepat waktu dan andal, sehingga dibutuhkan sebuah desain jaringan yang dapat menjaga kestabilan dan menjaga ketersedian jaringan yang tinggi dengan kemungkinan kehilangan data paling kecil sekalipun. Dalam sebuah desain jaringan yang mengutamakan kestabilan dibutuhkan protokol routing. Protokol adalah seperangkat aturan dan regulasi yang menentukan bagaimana data akan ditransfer di bidang jaringan komputer dan telekomunikasi (Rahman, dkk, 2017). Protokol routing dalam jaringan menentukan bagaimana router saling berkomunikasi satu sama lain dan bagaimana data yang ditransfer dari satu router ke router lainnya dan akhirnya ke tujuan (Ridwan, dkk, 2020). Selain itu, perlu melibatkan redundansi sebanyak mungkin dalam desain sebuah jaringan yang proporsional. Redundasi jaringan sendiri diartikan sebagai proses dimana perangkat tambahan atau alternatif perangkat jaringan, peralatan, dan media komunikasi dipasang dalam infrastruktur jaringan. Ini merupakan metode untuk memastikan jaringan tetap berjalan jika perangkat utama atau master mengalami kegagalan dalam jaringan. Pada penerapannya redundansi jaringan berfungsi sebagai mekanisme cadangan atau backup yang dengan cepat menukar operasi jaringan ke infrastruktur cadangan jika terjadi kegagalan jaringan yang tidak direncanakan. Umumnya redundansi jaringan diterapkan melalui penambahan jalur jaringan alternatif, yang diimplementasikan melalui router dan switch cadangan. Ketika jalur jaringan utama tidak tersedia, maka jalur jaringan alternatif dapat digunakan secara instan untuk memastikan jaringan tetap berjalan serta meminimalkan downtime pada jaringan.

First Hop Redundancy Protocol (FHRP) dapat didefinisikan sebagai sebuah protokol yang memungkinkan router cadangan atau backup dalam sebuah jaringan dapat secara otomatis mengambil alih jika router master terjadi kegagalan jaringan (Ibrahimi, dkk, 2017). FHRP memiliki tiga metode protokol utama yaitu Hot Standby Router Protocol(HSRP), Virtual Router Redundancy Protocol (VRRP), dan Gateway Load Balancing Protocol (GLBP). HSRP dikembangkan oleh CISCO dan merupakan salah satu protokol eksklusif mereka yang secara khusus dirancang untuk menggabungkan failover yang tidak mengganggu dan mendukung redundansi dalam jaringan (Wang \& Zhu 2012). HSRP merupakan salah satu protokol eksklusif mereka yang secara khusus dirancang untuk menggabungkan failover yang tidak mengganggu dan mendukung redundansi dalam jaringan. Namun, jika jaringan kehilangan protokol khusus ini, masing-masing dan setiap stasiun pada jaringan akan secara terpisah dikonfigurasi untuk berkomunikasi dengan router tertentu jika terjadi kegagalan, meskipun teknik ini tidak akan memberi kita redundansi tetapi akan membatasi jumlah stasiun yang akan terpengaruh oleh kegagalan gateway (Chaudhary, dkk, 2018). VRRP adalah protokol terbuka yang dapat digunakan pada beberapa vendor. Protokol ini menyediakan cara untuk memiliki satu atau lebih router backup saat menggunakan router yang dikonfigurasi secara statis pada jaringan LAN (Geng \& Huang 2018). Pengaturan yang paling umum adalah menentukan satu router untuk berfungsi sebagai router untuk meneruskan paket-paket dari sekelompok host pada jaringan LAN. Namun, jika router itu gagal, tidak ada cara untuk menggunakan router lain sebagai cadangan. Pada VRRP alamat IP virtual dapat ditentukan secara manual atau dengan Dynamic Host Configuration Protocol (DHCP) sebagai default (Saleem, dkk, 2014). Alamat IP virtual dibagikan di antara router, dengan satu ditunjuk 
sebagai router master dan yang lainnya sebagai cadangan atau backup. Jika router master gagal, alamat IP virtual dipetakan ke alamat IP router backup, sehingga router backup akan berfungsi sebagai router master (Dubey, dkk, 2013). Protokol GLBP adalah salah satu dari sistem FHRP yang menyediakan redundansi seperti protokol First Hop Redundancy lainnya. Protokol GLBP dan HSRP sama-sama merupakan milik CISCO, tetapi GLBP menyediakan load balancing melalui beberapa router menggunakan alamat IP virtual tunggal dan beberapa virtual mac (Batumalai, dkk,. 2015).

Beberapa penelitian mengenai penerapan sistem FHRP pada desain jaringan telah dilakukan. Ramdhani Syahputra (Syahputra, dkk, 2020) melakukan penelitian untuk menganalisa perbandingan kualitas layanan sistem VRRP dan GLBP dengan menggunakan protokol routing RIPV2 dan OSPF. Sistem FHRP yang didesain pada penelitian ini diterapkan pada jaringan berbentuk topologi ring dengan 8 buah router. Hasilnya menunjukkan bahwa sistem dengan protokol GLBP memiliki kecepatan sistem backup lebih baik dibandingkan protokol VRRP, sedangkan pada penerapan dengan topologi ring dan protokol routing hasilnya protokol VRRP lebih baik dibandingkan protokol GLBP. Pada penelitian yang dilakukan oleh Raja Ilango (Ilango, dkk, 2013) membahas teknik Dynamic Time Sync Reference Balancing untuk meningkatkan VRRP dengan fitur Dynamic load balancing yang memanfaatkan perangkat VRRP backup yang redundan dan berbagi beban lalu lintas jaringan. Dalam hal ini, perangkat utama VRRP memonitor durasi lalu lintas yang masuk dari segmen Jaringan Area Lokal Virtual (VLAN) tertentu dan mengalihkan lalu lintas jaringan ke perangkat backup VRRP jika perangkat utama VRRP masih memiliki sesi yang ada berdasarkan durasi dari arus lalu lintas dan jumlah sesi melalui basis data cache Netflow. Hasilnya VRRP dengan penambahan fitur pelacakan untuk memantau parameter Netflowdengan menerapkan Dynamic Time Syncyang membantu mengurangi kelemahan dari CPU pada perangkat router master VRRP yang bekerja secara berlebihan. Kemudian pemilihan parameter active flow dari Netflow untuk memastikan ketersediaan layanan jaringan.

Pada penelitian lain yang dilakukan oleh Choirullah (Choirullah, dkk, 2016) untuk menganalisis perbandingan kualitas layanan antara VRRP di jaringan VLAN dengan VRRP di jaringan tanpa VLAN ketika mengakses cloud storage dengan menggunakan perangkat router mikrotik. Parameter yang diuji pada penelitian ini adalah downtime, delay, throughput, retransmission, dan packet loss. Hasilnya kualitas layanan VRRP di jaringan VLAN lebih unggul dibandingkan VRRP di jaringan tanpa LAN. Penerapan sistem FHRP juga dilakukan dengan layanan streaming video seperti yang dilakukan oleh Akmaludin (Akmaludin, dkk, 2019). Penelitian ini berfokus mengevaluasi kinerja sistem FHRP milik Cisco yaitu HSRP dan GLBP dengan memanfaatkan sistem penyiaran digital berbasis video. Dari hasil simulasi pengujian ini didapatkan bahwa HSRP memiliki kinerja yang lebih baik dibandingkan GLBP, dimana parameter pengujian yang dilakukan adalah delay, packet loss, dan throughput.

Berdasarkan latar belakang dan beberapa penelitian diatas dapat diambil kesimpulan jika sistem FHRP sangat cocok diterapkan sebagai antisipasi apbila terjadi kegagalan pada router yang sedang bekerja. Disamping itu, sistem FHRP juga dapat diterapkan pada instansi atau organisasi yang membutuhkan sebuah sistem yang dapat menjaga kestabilan jaringan. Namun, dalam penelitian tersebut tidak ada yang membahas mengenai perbandingan dari ketiga sistem FHRP yang ada. Penelitian ini menitikberatkan pada perbandingan kinerja dari ketiga metode FHRP yaitu HSPR, VRRP, dan GLBP yang diterapkan pada jaringan backbone topologi star dengan menggunakan routing EIGRP. Alasan pemilihan topologi star dikarenakan hasil yang ingin dicapai dapat diterapkan pada institusi pendidikan yang kebanyakan memakai topologi star. Penelitian ini juga bertujuan untuk menganalisis dan membandingkan management performance dari sistem FHRP berdasarkan parameter uji Quality Of Service 
(QoS), seperti delay, packet loss, dan throughput, sehingga kedepannya penelitian ini dapat digunakan sebagai bahan rujukan dan pertimbangan untuk membangun sistem backup router pada sebuah institusi dengan mempertimbangkan pemilihan sistem berdasarkan pada management performance yang tepat untuk diterapkan pada suatu jaringan.

\section{METODE PENELITIAN}

\subsection{Model Simulasi Jaringan}

Pada penelitian ini, penulis menggunakan metode simulasi komunikasi data dalam jaringan untuk menganalisa kinerja dari FHRP dengan melakukan percobaan simulasi pada protocol VRRP, GLBP, HSRP di jaringan redistribution dengan percobaaan topologi yang digunakan star dan mengintegrasikan EIGRP ke topologi jaringan yang digunakan.

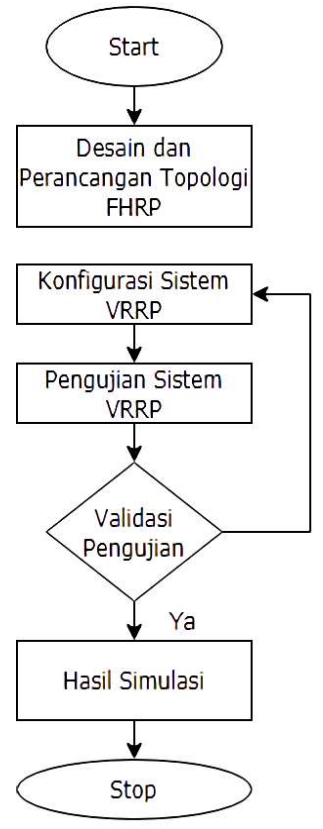

(a)

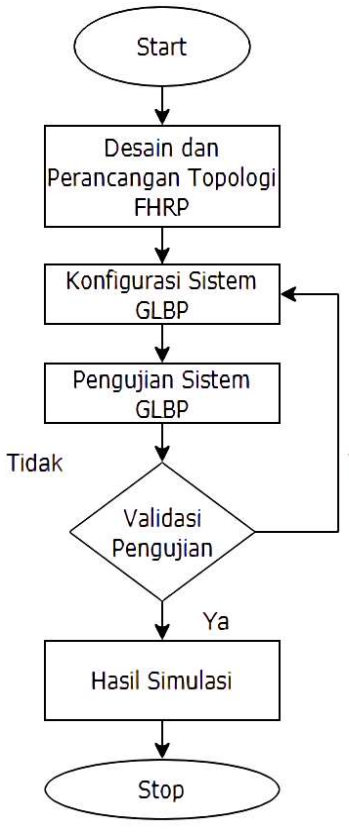

(b)
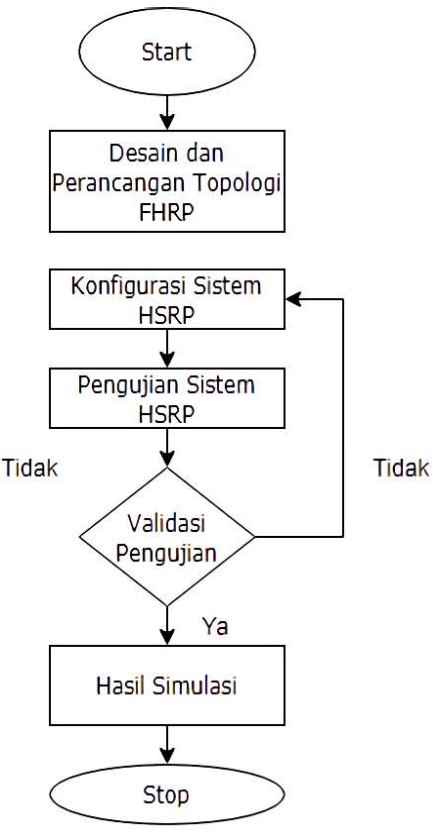

(c)

\section{Gambar 1. Flowchart Setting Perancangan Sistem FHRP (a) Konfigurasi VRRP (b) Konfigurasi GLBP (c) dan Konfigurasi HSRP}

Gambar 1 merupakan tahapan untuk setting pengujian simulasi sistem FHRP yang digunakan pada penelitian ini untuk mendapatkan analisis dari sistem tersebut. Konfigurasi sistem VRRP, GLBP, dan HSRP dilakukan masing-masing, karena ketiga protokol ini mempunyai metode yang berbeda-beda. Validasi dilakukan untuk memastikan berfungsinya konfigurasi pengujian dan mendapatkan hasil dari setiap protokol. Apabila terjadi kegagalan komunikasi data, maka akan dilakukan pengecekan kembali konfigurasi pada masing-masing protokol, sedangkan Gambar 2 merupakan tahapan selanjutnya dari penelitian ini dengan mengaplikasikan rancangan sistem FHRP ke topologi star menggunakan enam perangkat router CISCO di routing EIGRP sebagai jaringan internalnya. Dipilihnya routing EIGRP karena routing ini merupakan hybrid routing yang mengkombinasikan kelebihan dari link state dan distance vector (Syahputra, dkk, 2015), serta dipilihnya topologi star karena topologi ini memiliki fleksibilitas yang lebih baik dari pada topologi lain. 


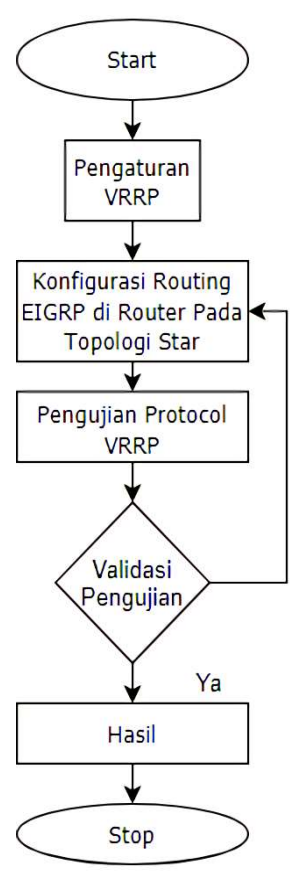

(a)

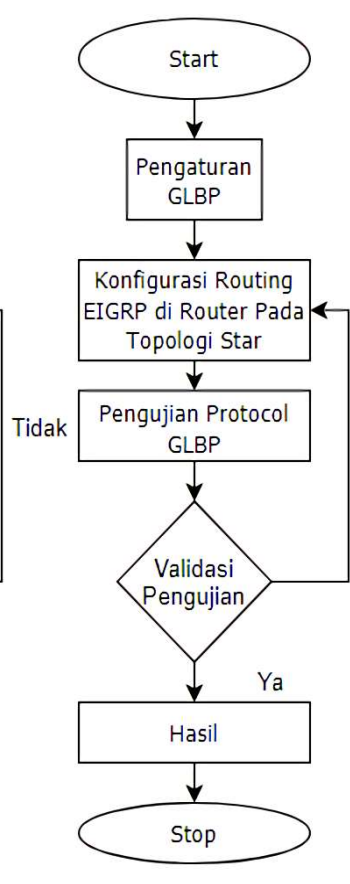

(b)

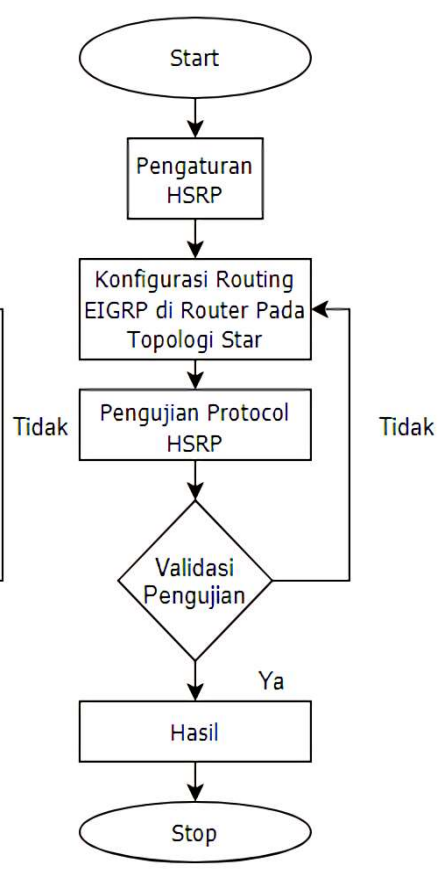

(c)

Gambar 2. Flowchart Setting Sistem FHRP (a) Konfigurasi VRRP (b) Konfigurasi GLBP (c) dan Konfigurasi HSRP di Routing EIGRP pada Topologi Star

\subsection{Desain Topologi FHRP}

Konsep utama atau master dari sistem FHRP membentuk sistem backup di router agar tidak terjadinya loss communication pada jaringan yang dapat merugikan suatu institusi, universitas atau perusahaan. FHRP memilih perangkat routeryang memiliki prioritytertinggi dari beberapa perangkat router untuk menjadi router master dan router yang memiliki priority lebih rendah untuk menjadi router backup yang berstatus standby ketika jaringan di akses pada router master, dan akan mengambil alih akses jaringan ketika router master dalam kondisi mati. Desain topologi sistem FHRP menggunakan 3 buah router, 2 buah switch dan 2 buah PC. Pada Gambar 3 merupakan desain dan rancangan sistem FHRP yang akan dilakukan pada penelitian ini dengan router 2 memiliki priority 100 dan router 3 memiliki priority 10.

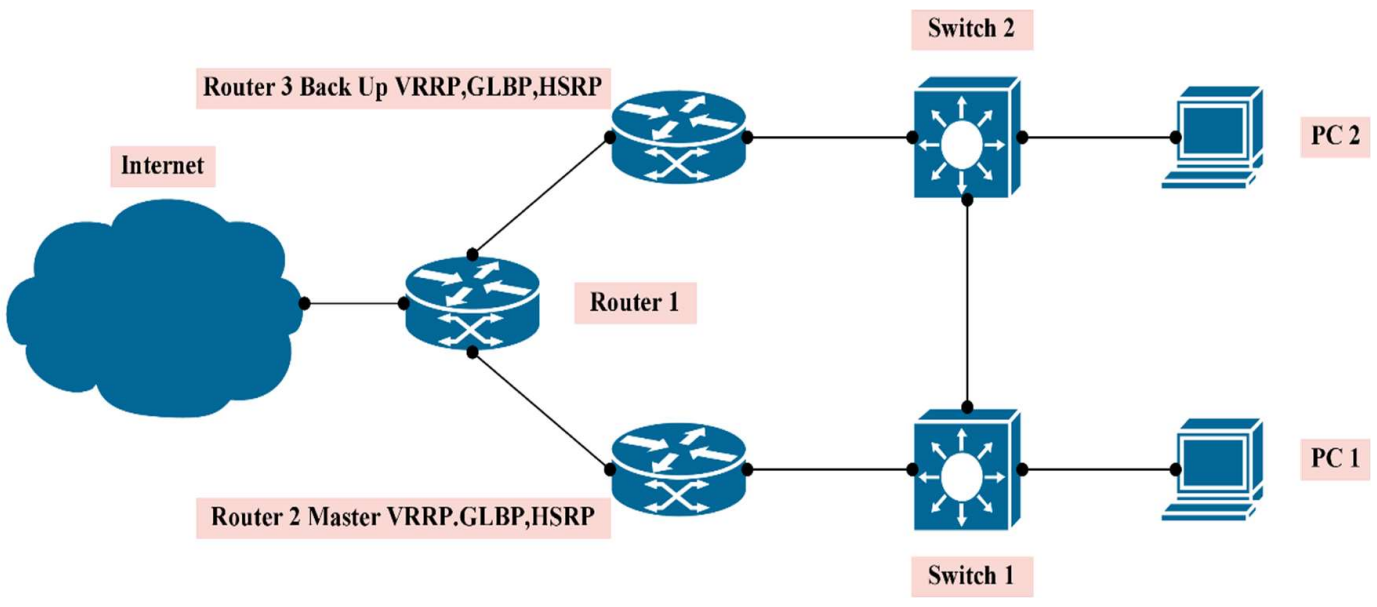

Gambar 3. Desain Sistem First Hop Redundancy Protocol 
Setiap protokol di sistem FHRP memiliki tujuan, kelebihan dan kekurangan sendiri. FHRP terdiri tiga protokol utama, yaitu VRRP, GLBP, dan HSRP dengan menyediakan redudansi, load balancing, serta failover. Di VRRP ada dua jenis router, yaitu router master dan router backup. Router master mengambil semua tanggung jawab pengiriman data dan mengirimkan pesan 'helld' ke router backup untuk menunjukkan status fungsionalnya. Router backup mulai berfungsi saat router master mengalami kegagalan dalam jaringan. Dalam VRRP, active gateway dianggap sebagai router master sementara sisanya mengambil peran router backup. VRRP menciptakan router virtual yang diberi alamat IP dan alamat MAC dan bekerja dengan mengelompokkan beberapa router menjadi satu router virtual dengan alamat IP-nya. Router virtual menerima semua lalu lintas yang dikirim oleh klien dan kemudian meneruskannya ke tujuan yang tepat. VRRP sangat mirip dengan HSRP dalam hal ini menggunakan gateway virtual tunggal yang dibagi antara router master dan router backup. HSRP adalah protokol milik CISCO yang menyediakan mekanisme untuk mendukung failover non-disruptive. Router master di HSRP termasuk router active, router standby, dan router listen. Router dengan prioritas tertinggi dipilih sebagai router active dan mentransmisikan semua data yang dikirim ke alamat MAC router. HSRP dan VRRP bekerja pada aturan prioritas yang lebih tinggi karena gateway dengan prioritas tertinggi dipilih sebagai router active atau master. Prioritas default adalah 100, dapat berkisar dari 0 hingga 255 jika lebih dari satu router gateway memiliki prioritas yang sama. Kedua protokol ini menyediakan redudansi dan failover, tetapi tidak menyediakan load balancing untuk menyeimbangkan beban kerja router.

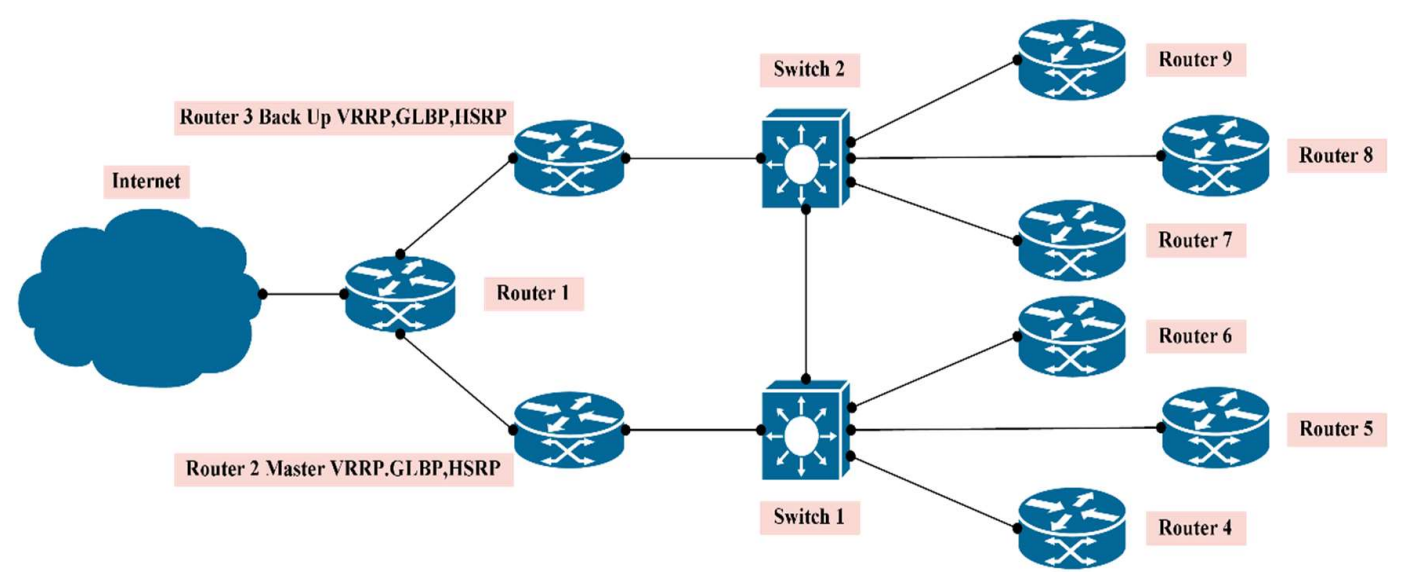

Gambar 4. Desain Jaringan Backbone dengan Sistem FHRP

GLBP mendukung penyeimbangan beban, kontinuitas jaringan dengan menyediakan load balancing, redudansi IP, dan failover. Ketika terjadi suatu kondisi dimana salah satu router dalam kondisi mati, protokol GLBP menawarkan prosedur pemulihan kegagalan jaringan yang lebih handal serta penghematan sumber daya yang tersedia agar tidak terbuang sia-sia. Hal ini disebabkan karena semua router yang tersedia bekerja seperti router active atau master, sehingga mencegah seluruh sistem jaringan terputus. Pada protokol HSRP dan VRRP hanya memungkinkan satu perangkat untuk mentransfer lalu lintas paket ke tujuan yang akan menyebabkan kehilangan bandwidth yang cukup besar dari router yang berstastus standby. GLBP dapat mengatasi masalah ini dengan dua peran utama gateway, yaitu dengan Active Virtual Gateway (AVG) dan Active Virtual Forwarder(AVF). Gateway dengan prioritas tertinggi dianggap sebagai AVG. Peran utama AVG adalah membalas Address Resolution Protocol(ARP) yang meminta alamat IP secara rahasia. AVG juga menggunakan berbagai alamat MAC secara rahasia dalam menanggapi permintaan ARP untuk memfasilitasi distribusi beban, dan router yang tersisa bertindak sebagai backup untuk AVG. AVG memberikan alamat MAC virtual untuk setiap router GLBP. Gateway ini akan berubah menjadi AVF untuk mencari alamat MAC virtual, 
yang memiliki tanggung jawab untuk meneruskan paket ke router lain atau ke tujuan. Pada protokol GLBP baik AVF dan AVG memiliki backup dengan cara yang mirip dengan router active atau master di HSRP dan VRRP. Ketiga protokol ini menggunakan algoritma authentications md5 key-string kits. Algoritma ini melakukan pengiriman paket hello yang standarnya setiap 1 detik ke setiap perangkat router. Pada sistem FHRP router-router akan saling berkomunikasi dengan cara mengirimkan pesan hello. Pengiriman pesan hello ini berfungi untuk pengecekan kondisi router master apabila terputusnya jaringan. Jika router master tidak membawa paket hello selama 10 detik, maka router master dalam keadaan mati, sehingga router backup akan mengambil semua tanggung jawab router master.

\subsection{Mekanisme Pengujian FHRP}

Pada penelitian ini, penulis menggunakan software simulasi Graphical Network Simulator 3 (GNS) dan Wireshark. Mekanisme pengujian sistem FHRP dilakukan dengan perintah Internet Control Message Protocol (ICMP) antara PC1 dan PC2 ke router 2 dan router 3 sebagai router master dan backup. Ketika router 2 sebagai master di sistem FHRP dalam kondisi mati yang menyebabkan loss connection, maka router 3 sebagai backup akan otomatis mengambil seluruh tanggung jawab dari router master agar tidak terjadinya loss connection yang cukup lama dengan menerapkan metode redundancy, load balancing, dan active-standby-listen router yang ada pada FHRP. Berdasarkan parameter yang diujikan pada sistem FHRP didapatkan hasil yang memiliki perbedaan kinerja jaringan ketika tanggung jawab jaringan berada di router master maupun pada kondisi router master mati. Untuk implementasi sistem FHRP pada jaringan backbone di topologi star dengan enam perangkat router CISCO menggunakan routing EIGRP. Dimana setiap router akan melakukan proses ICMP ke router master dan backup pada sistem FHRP untuk mendapatkan kombinasi yang lebih baik dalam membangun sistem redundancy, load balancing, failover, dan backup dengan mempertimbangkan hasil analisis performance berdasarkan parameter yang digunakan. Untuk menganalisis kinerja dari sistem FHRP dengan metode redundancy, load balancing, dan active-standby router digunakan persamaan sebagai berikut :

$$
\begin{gathered}
\text { Delay Average }(\mathrm{s})=(\text { Waktu Pengiriman Paket }) /(\text { Total Paket }) \\
\text { Packet Loss }(\%)=(\text { Paket Hilang }) /(\text { Paket Total }) \times 100 \% \\
\text { Throughput }(\text { Kbps })=(\text { Jumlah Data yang Dikirim }) /(\text { Waktu Pengiriman Data })
\end{gathered}
$$

Dari persamaan yang digunakan pada penelitian ini maka didapatkan hasil kombinasi dari performance redundancy, load balancing, failover dan backup router serta performance protocol di FHRP ketika dikombinasikan dengan dynamic routing EIGRP di topologi star. Penelitian ini dilakukan dengan menerapkan 2 skenario, skenario pertama melakukan pengujian pada sistem FHRP yang dirancang, dan skenario ke dua yaitu implementasi sistem FHRP ke topologi star dengan jumlah paket yang dikirimkan sebesar 512 Kbps untuk setiap skenario pengujian dan waktu simulasi dilakukan selama 120 detik.

\section{HASIL DAN PEMBAHASAN}

\subsection{Protokol Address Resolution Protocol(ARP)}

Pada penelitian ini, komunikasi data dalam protokol VRRP, GLBP, dan HSRP untuk setiap host atau PC saling berkomunikasi melalui MAC address. Apabila MAC address tujuan tidak diketahui, maka router akan mengirimkan ARP untuk mendapatkan MAC address dengan memanfaatkan IP address. Pesan yang dikirimkan ARP dari router dalam bentuk broadcast. Pada Gambar 5 merupakan hasil screen capture permintaan ARP pada salah satu sistem FHRP yang diujikan seperti pada kotak hitam yang ditunjukkan dengan kalimat who has 10.64.0.3?, 
dimana MAC address tujuan akan merespon jika telah menerima pesan broadcast dari ARP. Dapat dilihat bahwa ARP bertugas untuk menerjemahkan alamat IP address menjadi alamat fisik MAC address.

\begin{tabular}{|c|c|c|c|}
\hline 6228.039488010 .64 .0 .5 & $224 \cdot 0 \cdot 0.10$ & EIGRP & $74 \mathrm{Hello}$ \\
\hline $6328.919387010 .64 \cdot 0.3$ & $224 \cdot 0.0 .2$ & HSRP & 62 Hello (state Active) \\
\hline 6429.660525010 .64 .0 .9 & $224 \cdot 0.0 .10$ & EIGRP & 74 Hello \\
\hline 6530.261202010 .64 .0 .1 & 224.0 .0 .2 & HSRP & $62 \mathrm{Hello}$ (state standbv) \\
\hline $6630.5700260 c 0: 08: 21: 98: 00: 00$ & Broadcast & ARP & 60 who has $10.64 \cdot 0.3 ?$ Tell $10.64 \cdot 0.7$ \\
\hline $6730.7384000 \mathrm{c0}: 04: 08: 74: 00: 01$ & $c 0: 08: 21: 98: 00: 00$ & ARP & $6010.64 \cdot 0.3$ is at $c 0: 04: 08: 74: 00: 01$ \\
\hline $6830.933802010 .64 \cdot 0.4$ & 224.0 .0 .10 & EIGRP & $14 \mathrm{HellO}$ \\
\hline 6931.067725010 .64 .0 .8 & 224.0 .0 .10 & EIGRP & 74 Hello \\
\hline 7031.100707010 .64 .0 .7 & $224 \cdot 0 \cdot 0.10$ & EIGRP & $74 \mathrm{He} / \mathrm{O}$ \\
\hline $7131.2036480 \mathrm{c0}: 01: 23: b 4: 00: 00$ & \multicolumn{2}{|c|}{ CDP/VTP/OTP/PAgP/UDCDP } & 348 Device ID: R9 Port ID: Fastethernet $0 / 0$ \\
\hline $7231.761238010 .64 \cdot 0.3$ & $224 \cdot 0.0 .2$ & HSRP & 62 Hello (state Active) \\
\hline $7331.929143010 .64 \cdot 0.6$ & $224 \cdot 0.0 .10$ & EIGRP & 74 Hello \\
\hline
\end{tabular}

\section{Gambar 5. Frame Protokol ARP di HSRP}

\subsection{Parameter Delay (Latency) Average FHRP}

Delay merupakan rata-rata waktu untuk suatu paket menempuh jalur dari asal ke tujuan paket. Parameter delay dari kedua skenario pengujian didapatkan dengan menggunakan Persamaan 1, seperti ditampilkan pada Gambar 6 dibawah yang merupakan perbandingan delay average untuk setiap protokol di FHRP.

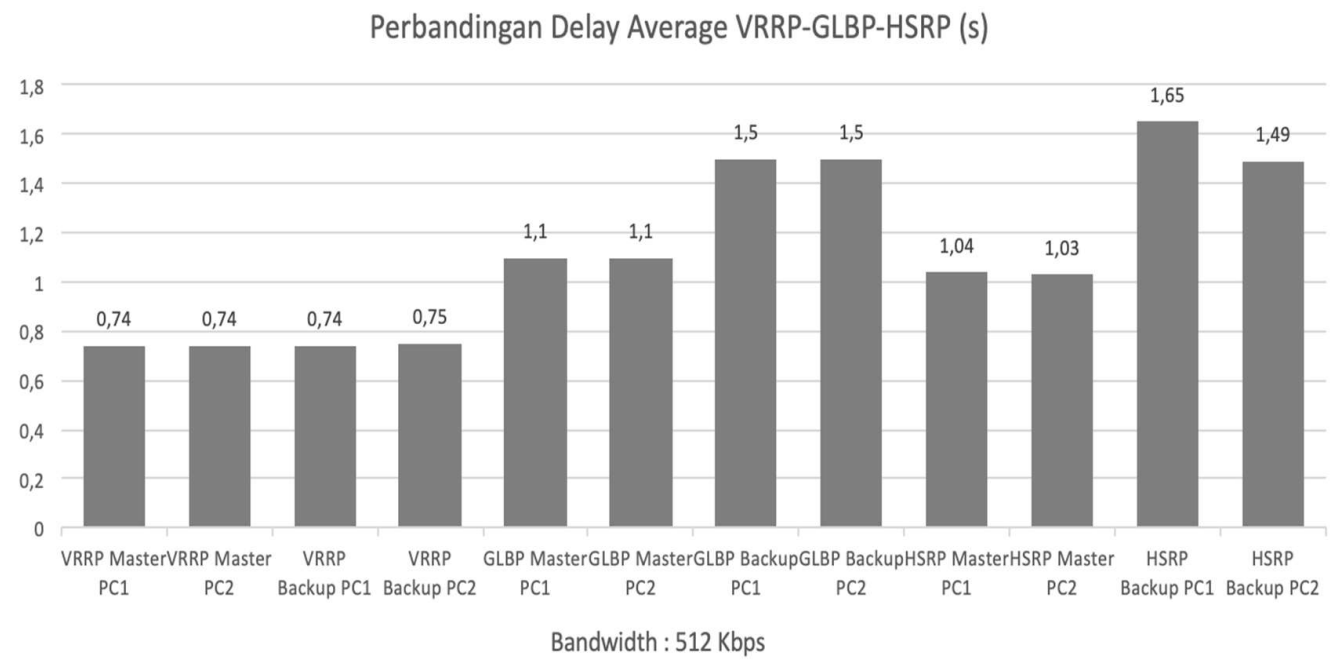

Gambar 6. Perbandingan Delay Average Sistem VRRP-GLBP-HSRP

Gambar 6 merupakan hasil pengujian delay average di skenario pertama. Hasil yang didapatkan terjadi kenaikan delay pada PC2 ketika router master mati, yaitu sebesar 1,33\% dibandingkan ketika router master dalam kondisi mati, sedangkan delay pada GLBP terjadi kenaikan sebesar 26,6\% ketika router master dalam kondisi mati. Untuk delay HSRP terjadi kenaikan delay sebesar 36,9\% ketika router master dalam kondisi mati. Dari hasil simulasi yang tampilkan pada Gambar 6, diketahui bahwa VRRP memiliki kinerja delay lebih baik dibandingkan dengan delay GLBP dan HSRP. Ketika sistem FHRP diaplikasikan pada topologi star yang merupakan skenario pengujian kedua dari penelitian ini hasil pengujian delay average ditampilkan pada Gambar 7 dan Gambar 8. Dari Gambar 7 dapat dilihat bahwa router master pada protokol VRRP memiliki nilai delay lebih kecil dibandingkan dengan delay di protokol GLBP dan HSRP saat diimplementasikan ke 6 perangkat routerCISCO dengan routing EIGRP. Perbedaan delay antara protokol VRRP dan protokol GLBP sebesar 17,1\%, sedangkan 
perbandingan delay antara VRRP dan HSRP sebesar 15,13\%. Perbedaan delay antara protokol HSRP dengan GLBP sebesar 2,31\%. Jadi dapat disimpulkan protokol VRRP memiliki delay paling kecil dibandingkan protokol HSRP dan GLBP.

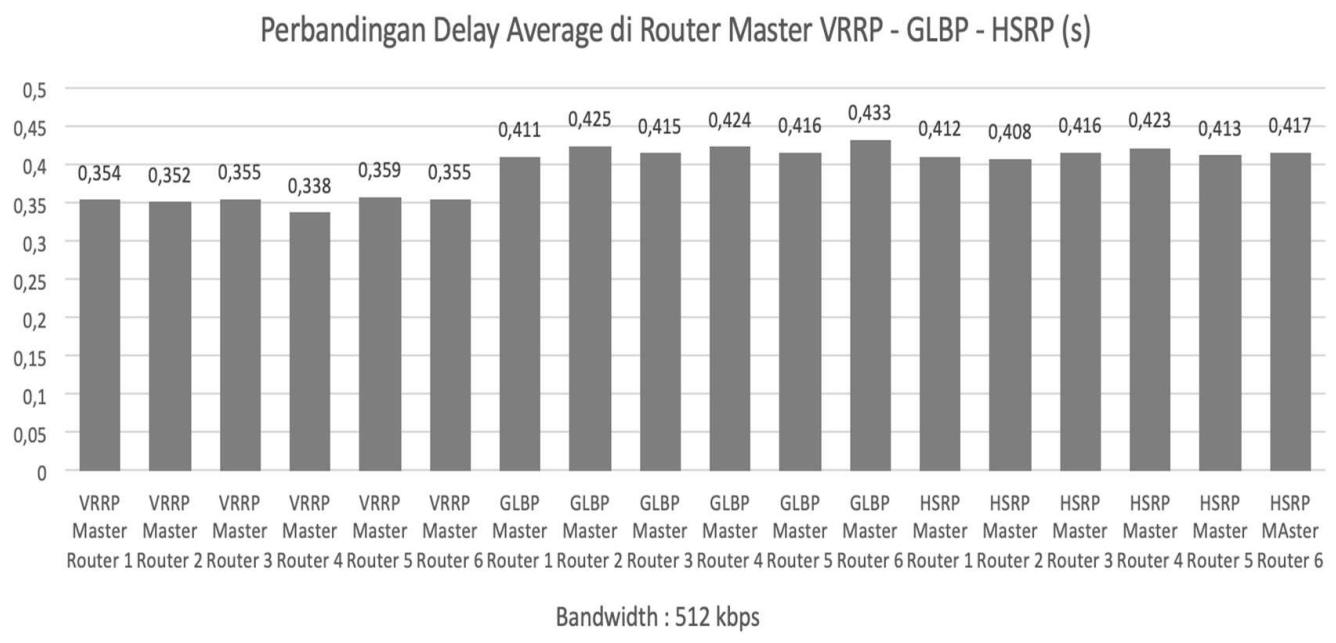

Gambar 7. Perbandingan Delay Average di Router Master Sistem VRRP-GLBP-HSRP

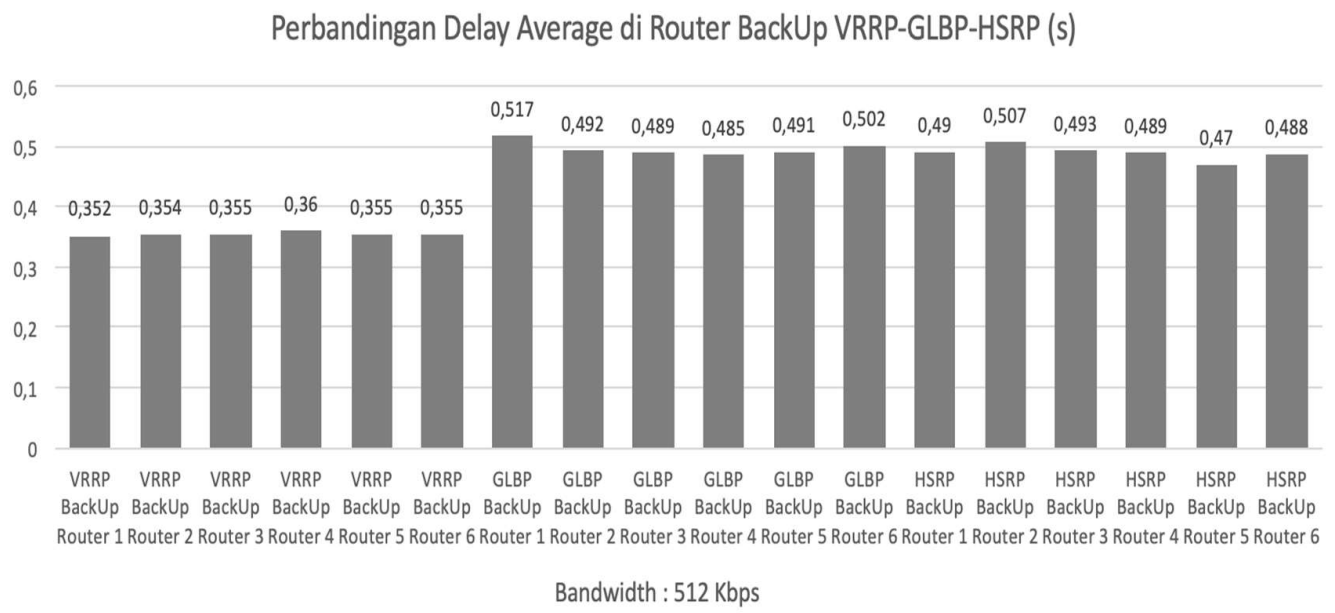

Gambar 8. Perbandingan Delay Average di Router BackUp Sistem VRRP-GLBP-HSRP

Hasil pengujian delay yang terjadi ketika router master dalam kondisi mati, maka komunikasi data akan diakses pada router backup. Delay pada protokol VRRP tidak terdapat kenaikan selama kondisi jaringan terputus, sedangkan pada protokol GLBP terdapat kenaikan delay sebesar $16,24 \%$, dan pada protokol HSRP sebesar $16,6 \%$. Penyebab berbedanya hasil delay antara ketiga protokol FHRP ketika router master dalam kondisi mati adalah waktu yang dibutuhkan oleh pesan hello yang melakukan pengecekan kondisi dari router master. Pada protokol VRRP pesan hello akan melakukan pengecekan setiap 1 detik, sedangkan pada protokol HSRP dan GLBP dilakukan setiap 3 detik. Hal ini tentunya mempengaruhi besarnya nilai delay, karena router backup memerlukan waktu untuk mengambil alih tanggung jawab jaringan di router master. 


\subsection{Parameter Throughput FHRP}

Throughput umumnya identik dengan bandwidth aktual yang diukur dalam satuan waktu. Jika bandwidth adalah batas maksimum, maka nilai throughput sesuai dengan data aktual pada transmisi. Namun throughput dipengaruhi oleh beberapa hal, seperti topologi jaringan, banyaknya penggunaan jaringan, dan tipe data yang di transfer. Untuk mendapatkan nilai throughput dari ketiga sistem FHRP pada penelitian ini, penulis menggunakan Persamaan 3. Pada Gambar 9 merupakan hasil perhitungan nilai throughput dari sistem FHRP yang diujikan pada penelitian ini.

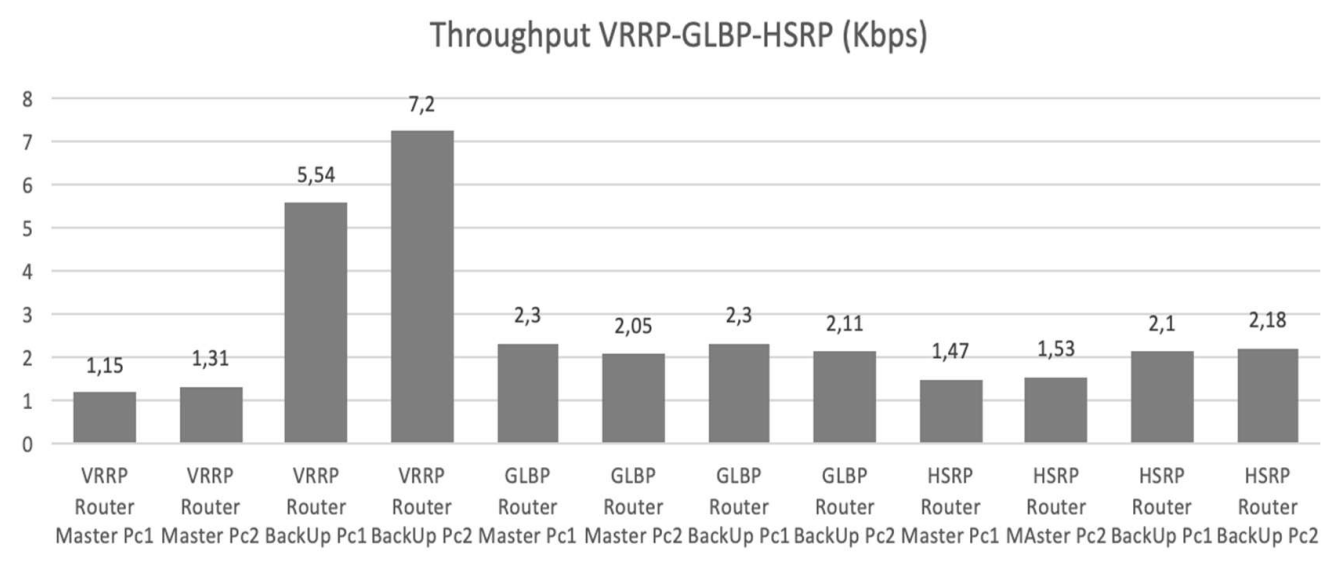

Bandwidth: 512 Kbps

\section{Gambar 9. Perbandingan Throughput Sistem VRRP-GLBP-HSRP}

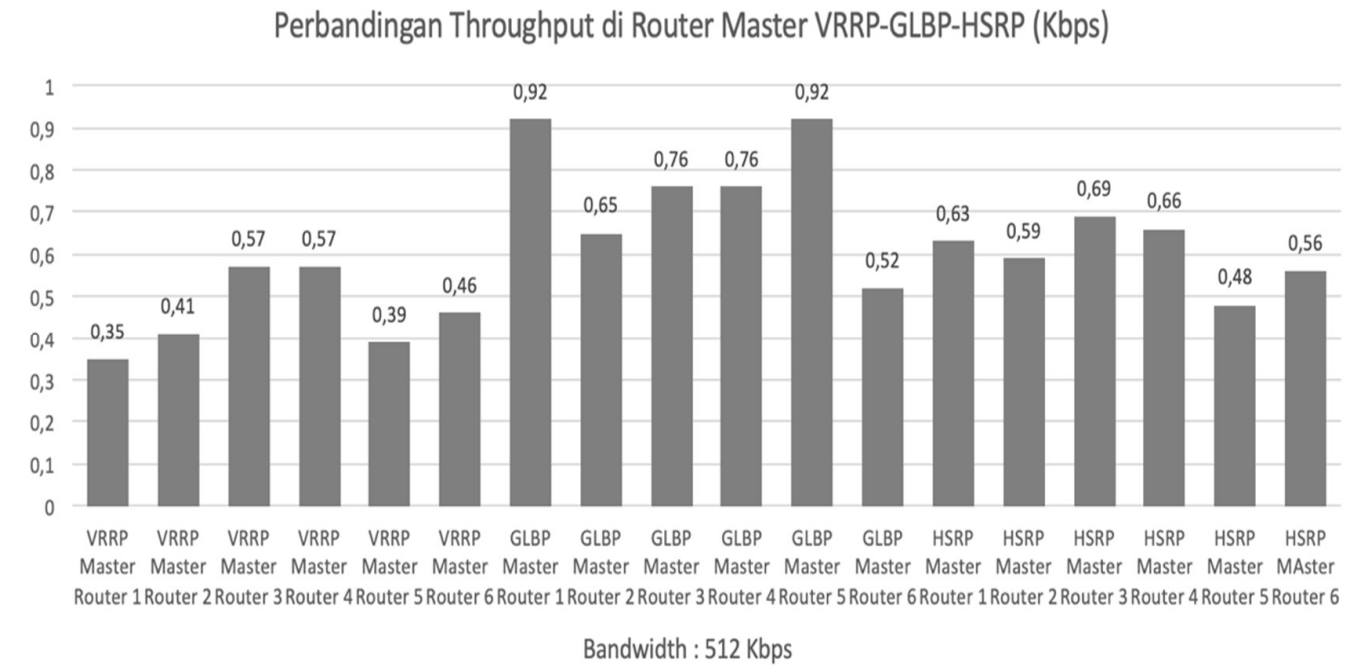

Gambar 10. Perbandingan Throughput di Router MasterSistem VRRP-GLBP-HSRP

Throughput pada protokol VRRP terjadi kenaikan sebesar $81,8 \%$ ketika router master dalam kondisi mati. Throughput pada GLBP juga terjadi kenaikan sebesar $9 \%$, serta pada HSRP kenaikan nilai troughput sebesar 29,8\%. Meskipun throughput pada protokol VRRP terjadi kenaikan yang cukup besar jika dibandingkan dengan GLBP dan HSRP. Namun, ketika jaringan dalam kondisi normal tanpa terjadi terputusnya jaringan pada router master, protokol VRRP memiliki nilai throughput lebih rendah dibandingkan throughput di GLBP dan HSRP. Hasil 
throughput ketika protokol VRRP, GLBP, dan HSRP diimplementasikan pada jaringan backbone dengan topologi star dapat dilihat pada Gambar 10 dan Gambar 11.

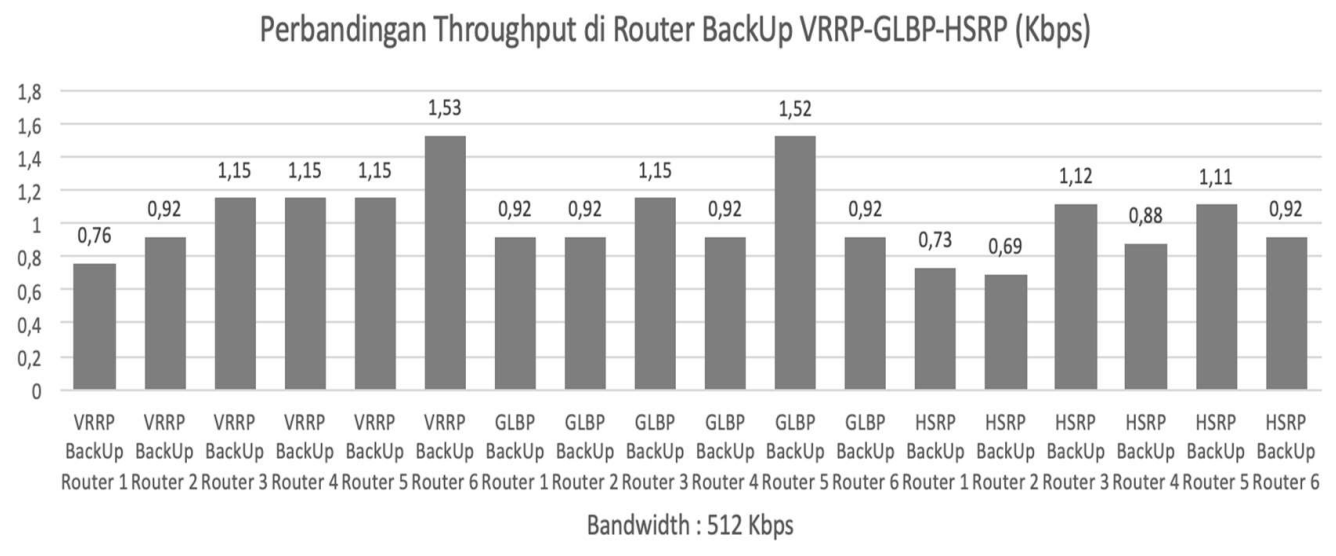

\section{Gambar 11. Perbandingan Throughput di Router BackUp Sistem VRRP-GLBP-HSRP}

Kualitas layanan throughput protokol VRRP lebih kecil dibandingkan GLBP dan HSRP. Protokol VRRP memiliki throughput lebih kecil 38\% dari throughput protokol GLBP, dan 17,4\% lebih kecil dari pada HSRP, sedangkan kualitas throughput protokol HSRP lebih baik sebesar $25 \%$ dari pada throughputprotokol GLBP untuk setiap masing-masing perangkat routerCISCO yang digunakan dalam penelitian ini. Pada hasil pengujian kualitas nilai throughput dengan mekanisme pengujian router master dalam kondisi mati atau kerusakan pada perangkat yang menyebabkan komunikasi data terputus maka router backup menggantikan peran router master dalam menyediakan akses komunikasi data yang ditampilkan pada Gambar 11. Dari ketiga protokol sistem FHRP, jika router master dalam kondisi mati terjadi kenaikan nilai throughput sebesar $62,7 \%$ pada protokol VRRP, sedangkan untuk protokol GLBP sebesar $39,5 \%$, dan 38,3\% pada protokol HSRP. Meskipun protokol VRRP terdapat kenaikan nilai kualitas layanan throughput yang cukup besar, tetapi protokol VRRP masih memiliki kualitas throughput yang lebih baik jika dibandingkan dengan protokol GLBP dan HSRP. Karena nilai hasil pengujian throughput berkaitan dengan bandwidth, maka hal ini menjadi penyebab nilai throughput pada protokol GLBP lebih tinggi dibandingkan protokol VRRP dan HSRP. Tingginya nilai throughput hasil pengujian dikarena pada protokol GLBP semua router akan bekerja sebagai router masteryang mengkomsumsi lebih banyak bandwidth. Berbeda dengan protokol VRRP dan HSRP yang hanya menggunakan satu router sebagai router master dan router lainnya sebagai router backup yang tidak mengkomsumsi bandwidth ketika router tersebut berstatus standby, sehingga kedua protokol ini mengkomsumsi sedikit bandwidth jika dibandingkan dengan protokol GLBP.

\subsection{Parameter Packet Loss FHRP}

Dalam Implementasi jaringan yang berbasis IP address, nilai packet loss diharapkan mempunyai nilai yang minimum. Umumnya packet loss terjadi karena packet yang dikirimkan gagal mencapai tujuannya. Dalam beberapa hal packet yang dikirimkan sengaja di jatuhkan oleh routing melalui teknik dissuasi jaringan untuk kepentingan manajemen operasional jaringan. Management performance packet loss dari sistem FHRP dihitung dengan Persamaan 2, hasil analisis dari sistem FHRP ditampilkan pada Gambar 12. 
Packet Loss VRRP-GLBP-HSRP (\%)

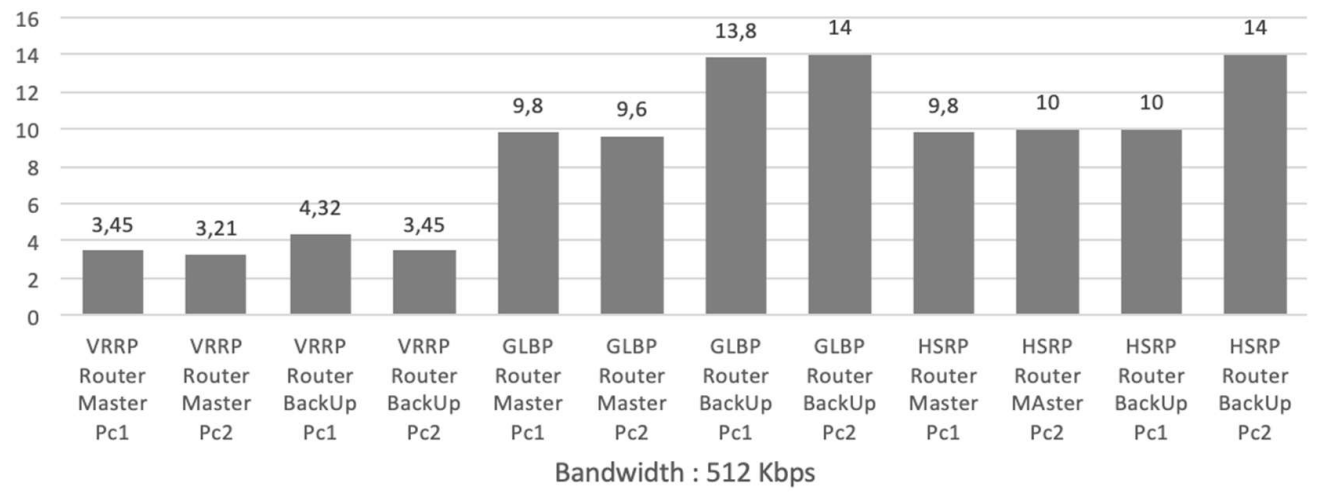

Gambar 12. Perbandingan Packet Loss Sistem VRRP-GLBP-HSRP

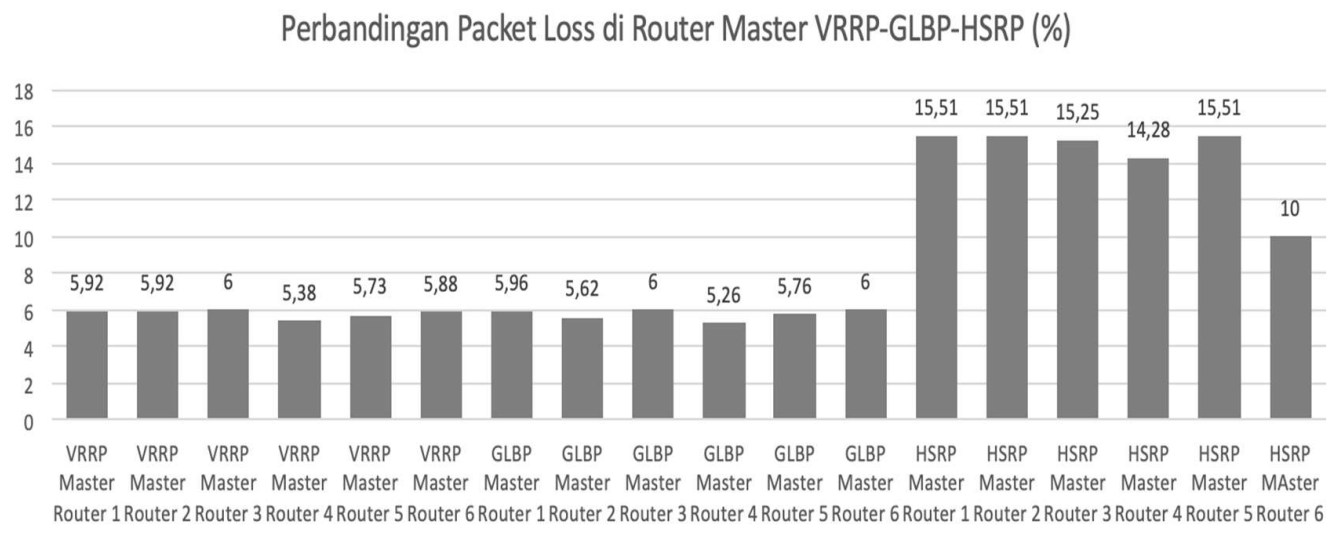

Bandwidth: 512 Kbps

\section{Gambar 13. Perbandingan Packet Loss di Router Master Sistem VRRP-GLBP-HSRP}

Selama pengujian sistem FHRP di router backup terjadi kenaikan kualitas layanan packet loss dibandingkan dengan router master sebesar 20,1\% pada protokol VRRP, dan 28,5\% pada protokol HSRP, sedangkan pada protokol GLBP kenaikan packet loss mencapai 30\%. Perbandingan management performance packet loss antara protokol VRRP dengan protokol GLBP sebesar $64,7 \%$, sedangkan pada protokol VRRP dengan protokol HSRP sebesar $65,5 \%$. Dapat disimpulkan bahwa kualitas layanan packet loss protokol VRRP lebih baik dibandingkan kualitas layanan packet loss protokol GLBP dan HSRP. Hasil pengujian kualitas layanan packet loss sistem FHRP yang diaplikasikan ke jaringan topologi star dengan routing EIGRP melalui mekanisme pengujian komunikasi data di router master dapat dilihat pada Gambar 13. Kualitas layanan packet loss pada protokol GLBP lebih besar 70,5\% dibandingkan packet loss protokol VRRP. Perbedaan kualitas layanan packet loss pada protokol HSRP masih lebih besar $61,3 \%$ dibandingkan protokol VRRP, sedangkan perbedaan packet loss protokol GLBP lebih kecil 2,8\% dibandingkan kualitas layanan packet loss protokol HSRP. Apabila router master dalam kondisi mati, kualitas layanan packet loss pada protokol VRRP, GLBP, dan HSRP dapat dilihat pada Gambar 14. 


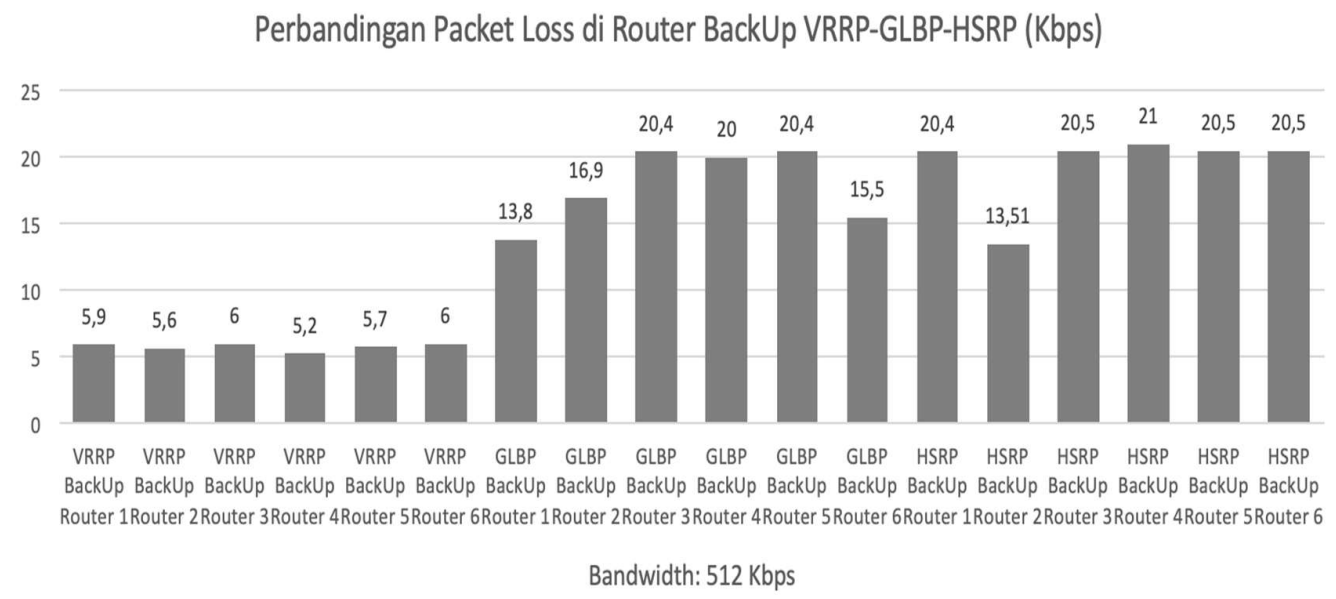

Gambar 14. Perbandingan Packet Loss di Router BackUp Sistem VRRP-GLBP-HSRP

Berbeda dengan kualitas layanan delay dan throughput ketika akses komunikasi data di router backup terjadi kenaikan persentase nilai kualitas layanan ketika router master mati. Pada kualitas layanan packet loss protokol VRRP, GLBP maupun HSRP tidak terjadi kenaikan persentase ketika jaringan di akses melalui router backup dengan routing EIGRP yang digunakan pada jaringan backbone. Hasil pengujian packet loss protokol VRRP, HSRP, dan GLBP diketahui bahwa router master dan router backup akan berkomunikasi melalui pesan hello setiap 1 detik dan 3 detik serta akan mendeteksi jika router master dalam kondisi mati . Ketika jaringan di router master terputus, maka router master tidak akan membawa pesan hello dalam periode default selama 10 detik, sehingga protokol VRRP, GLBP dan HSRP tidak dapat mendeteksinya, karena router master akan dianggap mati. Penyebab terjadinya peningkatan packet loss pada protokol VRRP, GLBP dan HSRP adalah jaringan yang terputus pada router master, dengan begitu router backup memerlukan waktu untuk mengambil alih tanggung jawab jaringan di router master. Berbeda dengan VRRP dan HSRP yang menggunakan satu router master, pada protokol GLBP semua router berfungsi sebagai router master, sehingga ketika salah satu router mati, maka akan terjadi peningkatan kualitas layanan packet loss, dan router yang dalam kondisi mati memerlukan waktu untuk kembali menjadi router master.

\section{KESIMPULAN}

Protokol VRRP, GLBP dan HSRP dikembangkan oleh CISCO untuk menyediakan kestabilan, dan keandalan komunikasi data pada jaringan khususnya pada router. Dari hasil pengujian yang dilakukan dengan paket yang dikirimkan sebesar $512 \mathrm{~Kb}$ dengan waktu simulasi selama 120 detik diketahui terjadi kenaikan delay, throughput, dan packet loss di protokol VRRP, GLBP, dan HSRP. Hasil analisis evaluasi sistem FHRP pada penelitian ini, dapat disimpulkan bahwa dari ketiga sistem FHRP yang di aplikasikan ke jaringan topologi star pada 6 perangkat router CISCO dengan menggunakan routing EIGRP terjadi kenaikan delay dan throughput. Namun pada kualitas layanan packet loss tidak terjadi kenaikan persentase pada protokol VRRP ketika router master mati. Pada protokol VRRP pengiriman pesan hello dilakukan setiap 1 detik, sedangkan pada protokol GLBP dan HSRP pengiriman pesan hello dilakukan setiap 3 detik yang memerlukan konsumsi bandwidth pada jaringan. Untuk melakukan pengecekan status router master yang mati dibutuhkan waktu 10 detik oleh pesan hello. Hal ini tentunya akan mempengaruhi kualitas delay, packet loss, dan throughputyang didapatkan dari pengujian ini. Dari ke tiga sistem yang ada pada FHRP, didapatkan kesimpulan bahwa sistem VRRP memiliki 
kualitas layanan dan kinerja yang lebih baik dari pada GLBP, dan HSRP baik ketika akses komunikasi data di router master maupun pada router backup.

\section{DAFTAR RUJUKAN}

Akmaludin, A., Arini, A., \& Masruroh, S. U.. (2019). Evalusi Kinerja Hot Standby Router Protocol ( HSRP ) Dan Gateway Load Balancing Protocol ( GLBP ) Untuk Layanan Video Streaming. CyberSecurity Dan Forensik Digital, 2(1), 43-51.

APJII. (2019). Penetrasi Dan Perilaku Pengguna Internet Indonesia. Retrieved May 9, 2020 (https://apjii.or.id/content/read/39/410/Hasil-Survei-Penetrasi-dan-PerilakuPengguna-Internet-Indonesia-2018).

Batumalai, S. K., Soon, J. N. P., Yin, C. P., Wan, W. S., Yuen, P. K., \& Heng, L. E. (2015). IP Redundancy and Load Balancing With Gateway Load Balancing Protocol. International Journal of Scientific Engineering and Technology, 4(3), 218-22.

Chaudhary, P. K., Kumar, R., \& Kaushik, S. (2018). Design and Simulate HSRP Protocol Based Network on Packet Tracer. International Journal of Engineering Science and Computing, 8(12),19600-605.

Choirullah, M. Y., Anif, M., \& Rochadi, A. (2016). Analisis Kualitas Layanan Virtual Router Redundancy Protocol Menggunakan Mikrotik Pada Jaringan VLAN." Jurnal Nasional Teknik Elektro Dan Teknologi Informasi (JNTETI), 5(4), 278-85.

Dubey, P., Sharma, S., \& Sachdev, A. (2013). Review of First Hop Redundancy Protocol and Their Functionalities. International Journal of Engineering Trends and Technology (IJETT), 4(5), 1085-88.

Geng, Q., \& Huang, T. (2018). VRRP Load Balance Technology Simulation Practice Based on GNS3. MATEC Web of Conferences 228 228, (pp. 4-6).

Ibrahimi, M. H., Vora, K. B., \& Khimani, K. (2017). Deploy Redundancy of Internet Using First Hop Redundancy Protocol and Monitoring It Using IP Service Level Agreements (IPSLA). International Journal of Engineering Science and Computing (IJESC), オ10), 15320-22.

Ilango, A., Raja, P., Kumar, K., \& Geetha, A. (2013). Dynamic Time Sync Reference Load Balancing in Virtual Router Redundancy Protocol. Middle - East Journal of Scientific Research, 2(5), 1128-31.

Rahman, Z. U., Mukhtar, S., Khan, S., Khan, R., Ullah, Z., Rashid, R. \& Ahmad, W. (2017). Performance Evaluation of First HOP Redundancy Protocols ( HSRP , VRRP \& GLBP ). Journal of Applied Environmental and Biological Sciences, 73), 268-78. 
Ridwan, A., Ferdian, R., \& Kurnia, R. (2020). Optimasi Protokol LEACH Untuk Meningkatkan Stabilitas Pada Wireless Sensor Network. Jurnal RESTI (Rekayasa Sistem Dan Teknologi Informasi), 1(1),193-200.

Saleem, H. M., Hassan, F. M., \& Bukhari, S. M. (2014). Router Redundancy with Enhanced VRRP for Intelligent Message Routing. The First International Conference on Soft Computing and Data Mining (SCDM-2014), 287, (pp. 581-90).

Syahputra, R.,Kurnia, R., \& Ferdian, R. (2020). Analisis Perancangan Dan Implementasi FHRP Di Protokol Routing RIPv2 Dan OSPF Ramdhani. Jurnal RESTI (Rekayasa Sistem Dan Teknologi Informasi), 1(1), 102-8.

Syahputra, R., Oktaviana, L., \& Safrianti, E.. (2015). Analisa Perbandingan Kinerja Routing Ripv1 EIGRP Dan OSPF Di PT. Chevron Pacific Indoneisa. Jurnal Online Mahasiswa Fakultas Teknik Universitas Riau, 2(1), 1-13.

Wang, F., \& Zhu, C. (2012). HSRP Protocol Based on High Reliable Redundant Campus Network Design." International Conference on Communication and Information Processing (ICCIP), (pp. 107-14). 